\title{
EXPLORING GROUNDWATER AQUIFERS USING GEOELECTRICAL TECHNIQUES IN WADI SAKHR AND ITS VICINITIES, NORTHWESTERN COAST, EGYPT
}

\author{
Zaghloul, Mohamed \\ Department of Geophysical Exploration, Desert Research Center, El- \\ Matareya, Egypt \\ E-mail: mz2790@hotmail.com
}

\begin{abstract}
$\mathrm{n}$ integrated geophysical survey including Vertical A Electrical Sounding (VES), Transient Electromagnetic 1 (TEM), and Electrical Resistivity Tomography (ERT) was conducted in the area of Wadi Sakhr, Northwestern Coastal Zone of Egypt. The objective of this survey is to characterize the conditions under which the groundwater occurs in the Middle Miocene carbonate rocks, which dominate the study area. The inversion results of 9 VES and 17 TEM measured sounding data revealed that the subsurface geoelectrical succession in most of the study area consists of five layers in addition to a sixth geoelectrical layer capping the succession at the northern part of the study area. The water-bearing zones were detected within the lower part of the third layer in the northern part of the area and the lower part of the fifth layer in the southern part of the study area. The inversion results of 11 ERT profiles revealed the detailed resistivity distribution of the subsurface layers and confirmed the results of both VES and TEM surveys. Besides, it resolved details of several subsurface features.
\end{abstract}

Keywords: Wadi Sakhr, Northwestern Coast, Vertical Electrical Soundings, transient electromagnetic, electrical resistivity tomography, groundwater

The rural communities who live in the inland areas of the Northwestern Coast of Egypt (NWC) depend on rainfall as a main water source for drinking, agriculture, and households. An insight into the decrease and alteration of the precipitation patterns and intensity during the last two decades shows signs of water scarcity. To withstand the problem of water shortage, people turn to groundwater as a supplement resource to the decreased and uncertain rainfall. The ever-growing demand for water has led to the need for more studies concerning the groundwater occurrences in the NWC. Therefore, the present geophysical study was conducted in the area of Wadi Sakhr, which lies in the Northwestern Coastal Zone between Ras El- 
Hekma at the East and Ras Alam El Rum at the west. It is bounded by longitudes $27.529^{\circ}$ and $27.58^{\circ} \mathrm{E}$ and by latitudes $31.122^{\circ}$ and $31.192^{\circ} \mathrm{N}$ (Fig. 1). Wadi Sakhr stream flows from south to north with its water divide at 8.5 $\mathrm{km}$ to the south of the Mediterranean Coast.

The major objective of this work is to characterize the conditions under which the groundwater occurs in the Middle Miocene carbonate rocks (Marmarica Formation), which dominate the study area. The geophysical survey included the application of Vertical Electrical Sounding (VES), Transient Electromagnetic (TEM), and Electrical Resistivity Tomography (ERT).

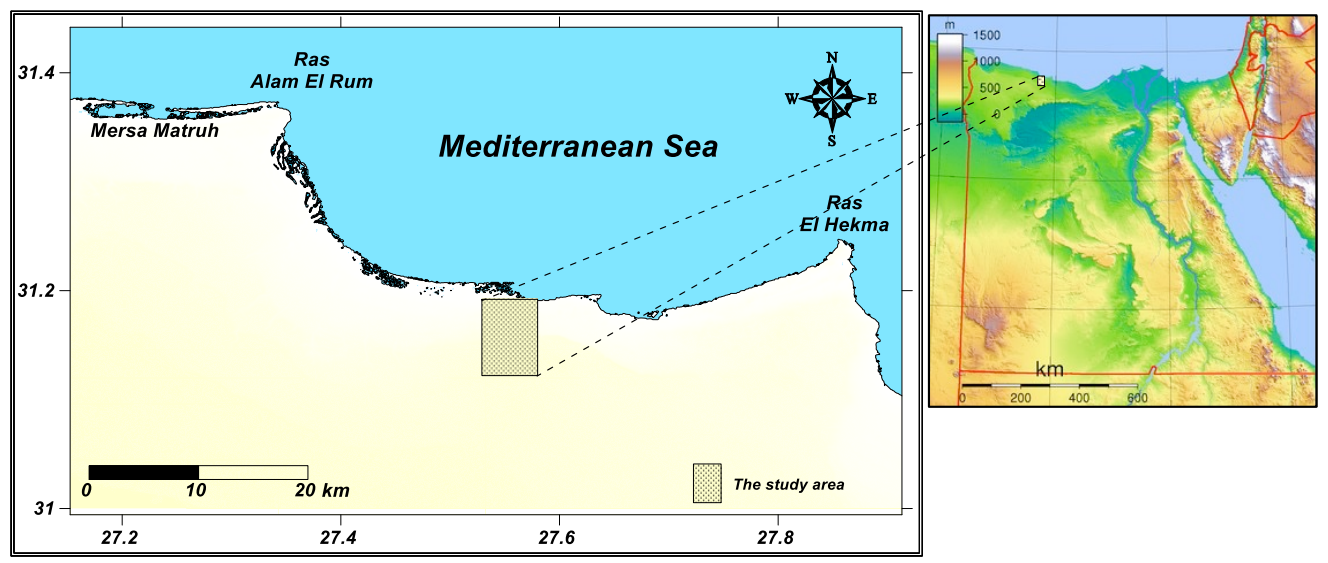

Fig. (1). Location map of the study area.

\section{MATERIALS AND METHODS}

\section{Physical Setting}

The northwestern coast of Egypt is characterized by semi-arid climatic conditions. The climate and the geologic conditions affect the present landforms of the area. As a part of the NWC, the area of Wadi Sakhr is distinguished into four main geomorphological units (Fig. 2); structural plateau (tableland), coastal plain, pediment plain, and drainage lines (Hammad, 1972 and Raslan, 1995). These units are regionally oriented nearly parallel to the present Mediterranean shore. The tableland constitutes a prominent geomorphologic unit bounding the coastal and pediment plains from the south. It occupies the northern extremity of the great Marmarican Homoclinal plateau and extends southward to the Qattara Depression. The tableland is composed mainly of fissured and jointed limestone which top portion is highly weathered and is developed into a hard-pink crust. The northern edge of the tableland is characterized by a well-developed escarpment facing north. The northern portion of the tableland area is 
dissected by many short and deep consequent valleys acting during rainy seasons as drainage lines. The tableland represents the main watershed area in the NWC. The pediment plain represents an extended sloping surface separating the tableland to the south from the coastal plain to the north. Its surface is covered with a thin layer of alluvial and sand deposits. The coastal plain occupies the peripheral zone parallel to the present Mediterranean shoreline. The coastal plain is characterized by the occurrence of a series of elongated ridges running parallel to the present shoreline, rising sometimes to more than $40 \mathrm{~m}$ above sea level, and attaining lower altitude towards the shoreline. These ridges represent ancient shorelines of the Mediterranean Sea and exhibiting different heights. The coastal ridges are generally composed of Oolitic limestone of different degrees of hardness. They act as watershed areas during rainy seasons.

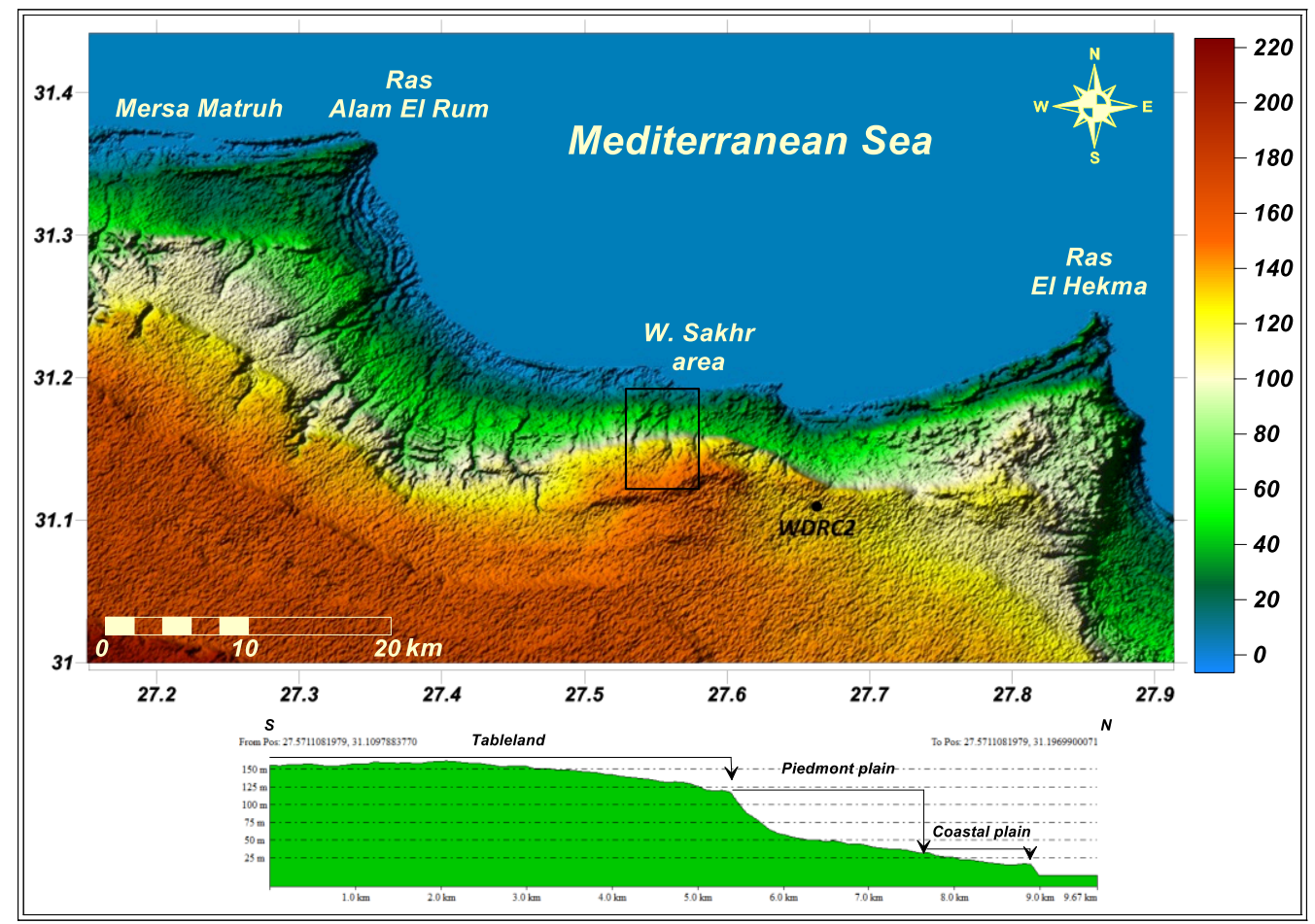

Fig. (2). Digital Elevation Model (DEM) of the study area and its surroundings and a S-N profile passing through the study area showing the geomorphological units.

According to Shata (1957), Said (1962), Shaaban (2004), El-Shazly (1970) and Yousif et al. (2013), the stratigraphic units which are exposed in the study area can be described from older to younger into the Tertiary and the Quaternary deposits (Fig. 3). The Tertiary deposits are exposed mainly in

Egyptian J. Desert Res., 70, No. 2, 153-171 (2020) 
the southern parts of the study area. They constitute the major part of the tableland and are mainly represented by the Middle Miocene sediments (Marmarica Formation). This formation is built up of fissured and cavernous limestone, dolomitic limestone, and sandy limestone intercalated partly with marl interbeds. The Quaternary is represented by the Pleistocene sediments and the overlying alluvial sediments. The Pleistocene sediments are widely distributed in the study area and are mainly represented by Oolitic limestone. It is almost developed in the form of ridges; these ridges are cross-bedded and composed of snow-white Oolitic sand grains, which are weakly cemented. The alluvial deposits cover the channels of the drainage lines in the form of Wadi terraces and Wadi fill. These deposits are muddy deposits composed of sand, silt, and clay with abundant carbonate grains.

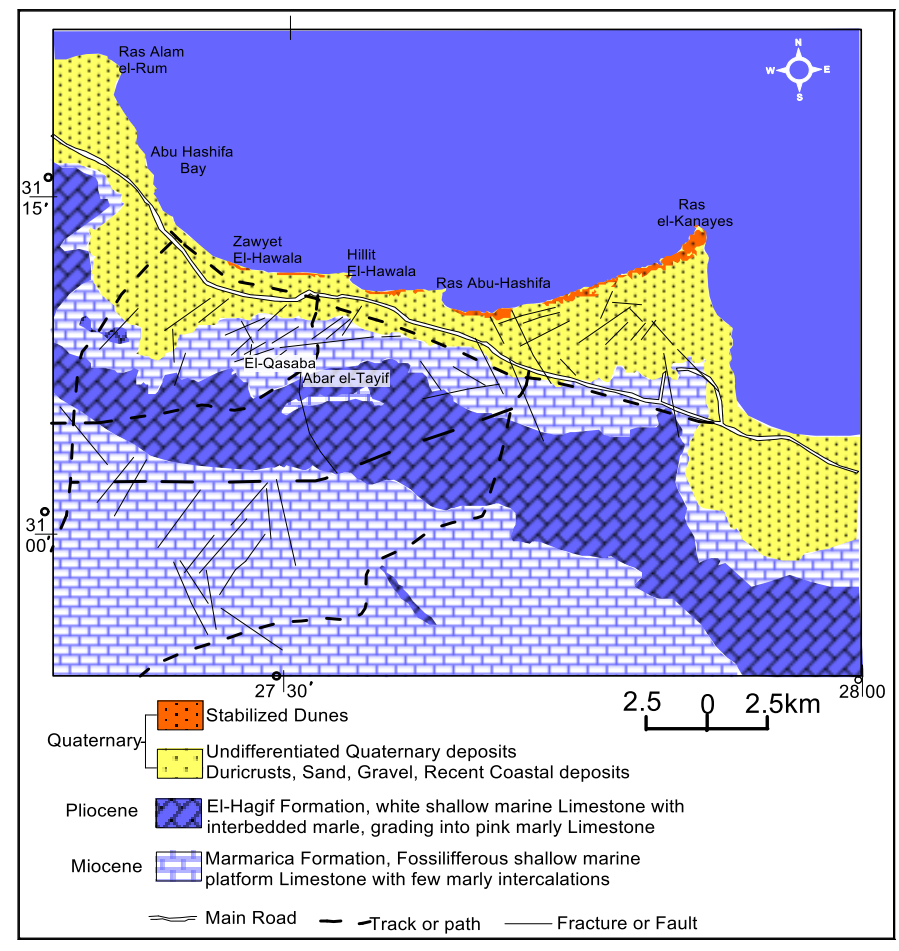

Fig. (3). Geological map of the study area and its surroundings (Modified after CONOCO, 1986).

Structurally, the Middle Miocene great homoclinal plateau is the most prominent structural feature. The northern extreme of the homoclinal plateau is affected by some monoclinal structures, dipping in a NE-SW direction. These monoclines have been detected in some localities along the coast in the form of headlands extending into the sea with NE-SW orientation, e.g., Ras El Hekma and Ras Alam El Rum. The regional tectonic 
movements, which affected the Northwestern coast resulted in fracturing of the Middle Miocene rocks. These fractures are oriented in different directions $\mathrm{E}-\mathrm{W}, \mathrm{NE}-\mathrm{SW}$, and $\mathrm{N}-\mathrm{S}$. The fractures contribute to the percolation of rainwater to replenish the groundwater in the Middle Miocene rocks.

\section{Hydrogeological Regime}

Several studies on the hydrogeology of the northwestern coast of Egypt have been achieved by Abdel Mogheeth et al. (1978), Sewidan (1978), El-Maghraby (1997), El-Raey (1998), El-Sharabi (2000), Soliman (2005), Morad et al. (2014) and Desert Research Center (2012 and 2018). They concluded that the NWC comprises three main water-bearing formations. From top downwards; these aquifers are the Quaternary aquifer (Oolitic limestone-Alluvial deposits), The Middle Miocene aquifer (Marmarica Formation), and the Lower Miocene aquifer (Moghra Formation). The Quaternary aquifer is restricted to the coastal parts with a thickness of few meters. It is composed of highly porous Oolitic limestone, calcareous gravel, and fine sands. A thin layer of freshwater is found floating on saline water. This aquifer is recharged from the infiltration of the precipitated water over its exposures. The water salinity of the Oolitic limestone aquifer is relatively higher than that of the alluvial deposits due to the high leaching processes. The Middle Miocene aquifer is the main source of groundwater. It is penetrated by numerous hand-dug and drilled wells with different depths. This aquifer is composed of limestone, yellowishgreen marl, and chalky limestone. The limestone is highly fractured favoring groundwater to accumulate and move. Groundwater occurs under unconfined conditions. The aquifer is underlain by either clay bed or compact limestone. The water salinity varies greatly from one locality to another. The Lower Miocene aquifer has been encountered at different depths in different wells along the NWC. It is composed of sandstone with shale interbeds. The water of this aquifer is generally saline.

\section{Field Data Acquisition}

The present integrated geophysical survey included the application of Vertical Electrical Sounding (VES), Transient Electromagnetic (TEM), and Electrical Resistivity Tomography (ERT). A total of 9 Vertical Electrical Soundings (VES) were measured by applying a Schlumberger array with maximum current electrode spacing differs from one VES to another (from 400 to $2000 \mathrm{~m}$ ). The field instrument (ABEM terrameter, SAS1000) was used to acquire the VES data. The Transient Electromagnetic (TEM) measurements were carried out at 17 sites in the study area with TEM-FAST 48 HPC instrument (Version 8) by employing a single square loop configuration (used as transmitter and receiver) with dimensions $200 \times 200$ $\mathrm{m}$ at 13 TEM soundings and $100 \times 100 \mathrm{~m}$ at 4 other soundings and current 
strength varies from 1- 4 A. The Electrical Resistivity Tomography (ERT) profile measurements were conducted at 11 sites. The Wenner electrodes array was used with a spacing start with $5 \mathrm{~m}$ and a total length of $175 \mathrm{~m}$ for 3 profiles, a spacing of $10 \mathrm{~m}$, and a total length of $350 \mathrm{~m}$ for 7 profiles and a spacing of $10 \mathrm{~m}$ and a total length of $710 \mathrm{~m}$ for 1 profile. The measurements were carried out by making use of the field instrument SYSCAL Pro 72 (Iris Instruments, France). The locations of the field measurements are shown in fig. (4). The longitudes and latitudes of the locations of the geophysical measurements were used to import their corresponding ground elevation with good accuracy from SRTM DEM 30 through the GIS software application (Global Mapper, v. 11.01, 2009).

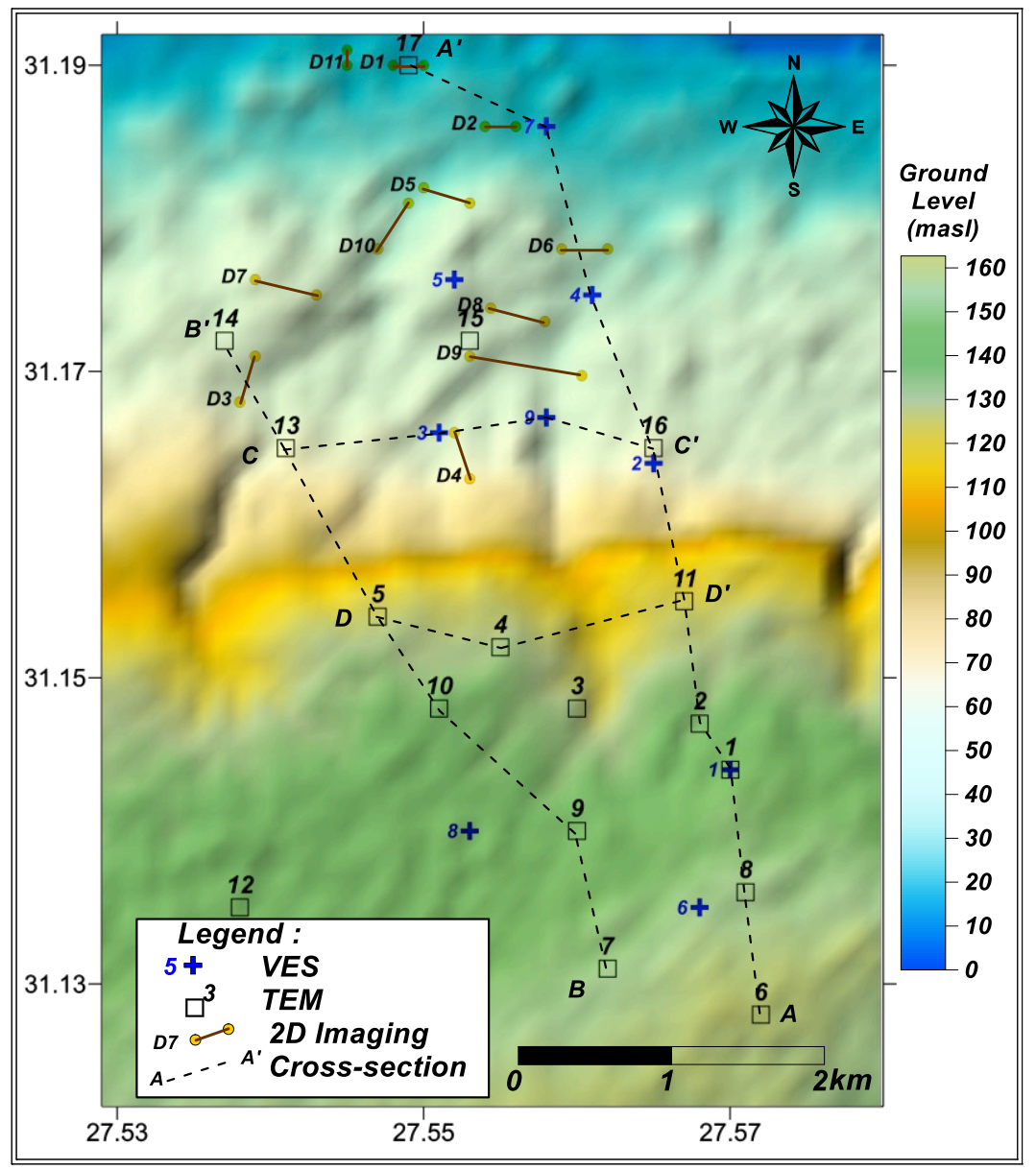

Fig. (4). Locations of the field measurements and constructed cross sections in the study area. 


\section{Inversion of TEM and VES Data}

According to Flores and Velasco (1998), the comparisons between theoretical and field one-dimensional (1-D) responses for the transient electromagnetic (TEM) and vertical electric sounding (VES) methods have shown that the VES method is sensitive to both resistive and conductive layers; but as these layers become thin, the problem of nonuniqueness or equivalence becomes severe. The TEM method is less severely affected by equivalence in the case of conductive layers, but may also be less sensitive to layers with high resistivities. So, taking advantage of each method can yield better results concerning the subsurface layering succession. Accordingly, the inversion of the TEM and VES data was made by using the model obtained from the inversion of the TEM data set as a reference or initial model to constrain the inversion of the VES data set .

Inversion of the TEM and VES data was made by using the software package IX1D (Interpex Limited, v. 3.39, March 2008). It is a software package for Windows Sx, which allows for forward and inverse modeling of TEM and VES data. Examples of TEM and VES inversion by using IX1D software are given in fig. (5). Unfortunately, there are no wells drilled in the study area, however, some information was obtained to assume the initial inversion model from a well located some $8 \mathrm{~km}$ east of the study area (Fig. 2). This well (DRC 2), which is shown in fig. (6) was drilled by the Desert Research Center (Desert Research Center, 2012).

\section{Inversion of the Electrical Resistivity Tomography (ERT) Data}

Inversion of the electrical resistivity tomography profiles was made by applying RES2DINV.EXE ver. 3.59.121 software (Geotom Software Sdn Bhd, 2009). It is a Windows-based computer program that automatically determines a two-dimensional (2-D) resistivity model for the subsurface for the data obtained from electrical imaging surveys (Dahlin 1996 and Loke et al. 2013). The topography along the profiles was added to the acquired measurements in order to visualize the true levels of the inversion layering model. 


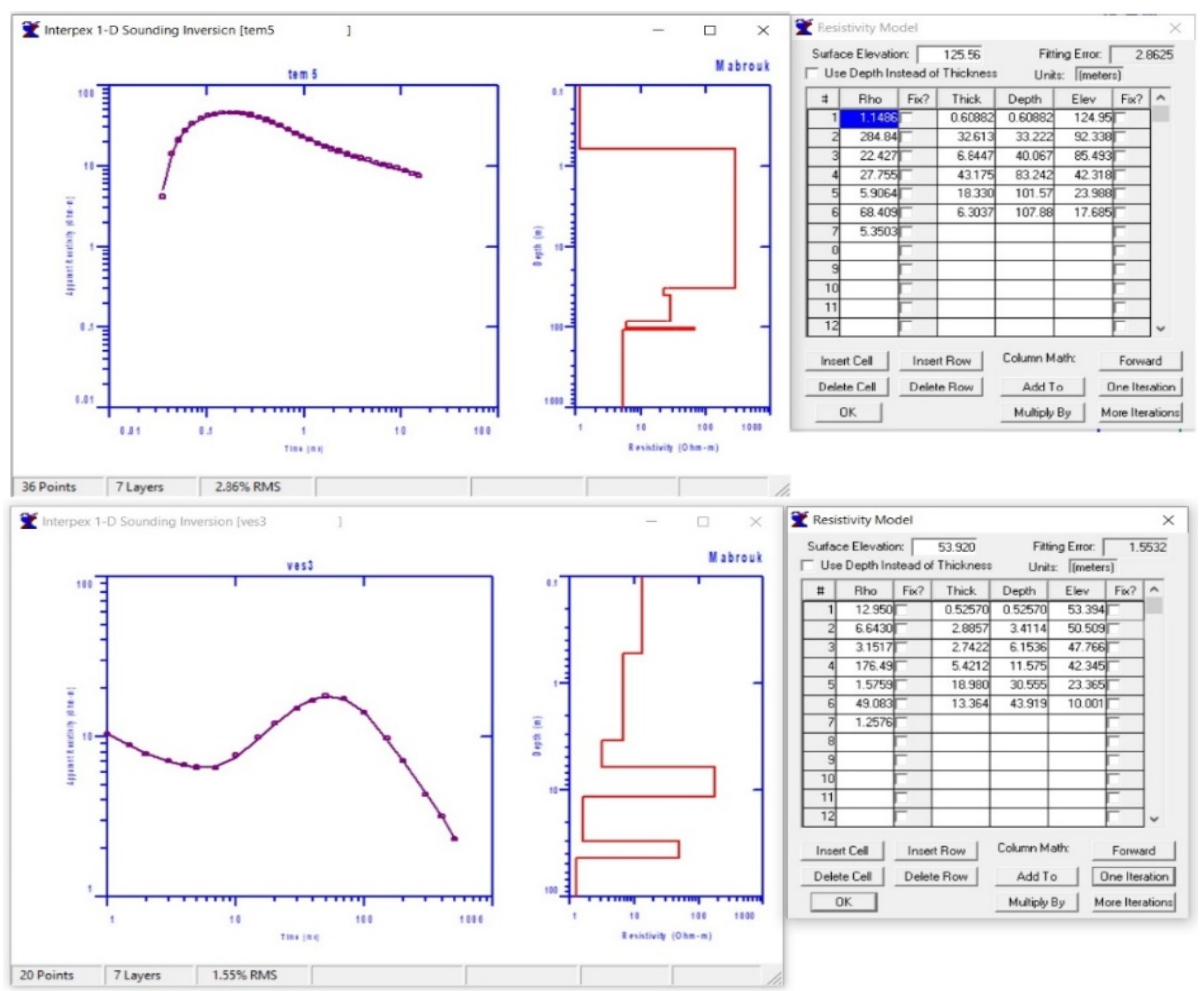

Fig. (5). Examples of the interpreted TEM and VES Soundings.

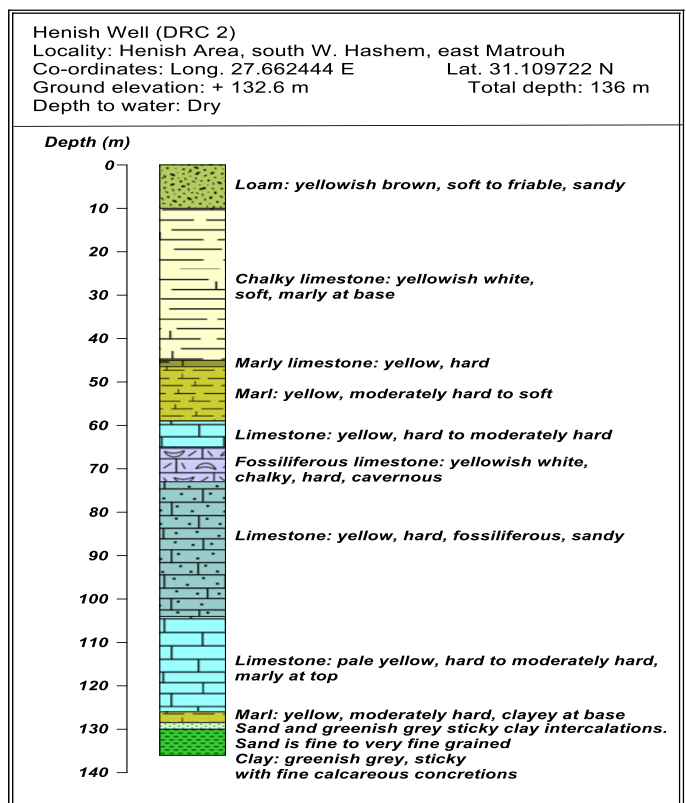

Fig. (6). Lithological description of DRC well (Located at $8 \mathrm{~km}$ east of the study area).

Egyptian J. Desert Res., 70, No. 2, 153-171 (2020) 


\section{RESULTS AND DISCUSSION}

The inversion of the TEM and VES sounding data revealed that the subsurface geoelectrical succession in most of the study area consists of five layers with alternating high and low resistivity. A sixth geoelectrical layer was encountered capping the succession at the northern part of the study area (the coastal plain). The ranges of the resistivity values and thicknesses of the encountered geoelectrical layers and their corresponding lithology are listed in table (1). From this table, it is clear that the first and third geoelectrical layers show a wide range of resistivity values. For the first layer, this feature is mainly due to merging the most upper thin layer/layers with the underlying main layer to give a single equivalent resistivity by making use of the transverse resistivity ( $\rho t)$. This parameter can be calculated from the resistivities and thicknesses of the succession of the thin layers as follows;

$$
\rho \mathrm{t}=\Sigma \text { ( } \rho \text { i.hi) } / \Sigma \text { hi ........ i }=1 \text { to } \mathrm{n}
$$

Where; $\rho$ i is the resistivity of the ith layer, hi is its thickness and $n$ is the number of layers.

Table (1). Minimum and maximum values of the resistivity and thickness of the interpreted geoelectrical layers as well as their corresponding lithology.

\begin{tabular}{|c|c|c|c|c|c|}
\hline \multirow{2}{*}{$\begin{array}{l}\text { Layer } \\
\text { no. }\end{array}$} & \multicolumn{2}{|c|}{ Resistivity [Ohmm] } & \multicolumn{2}{|c|}{ Thickness [m] } & \multirow[t]{2}{*}{ Lithology } \\
\hline & Minimum & Maximum & Minimum & Maximum & \\
\hline $\mathbf{L 1}$ & 28.5 & 280 & 2.5 & 64.5 & Chalky limestone \\
\hline $\mathbf{L 2}$ & 3.5 & 12.3 & 7 & 19 & Marl \\
\hline \multirow{2}{*}{$\mathbf{L 3}$} & 13 & 157 & 37 & 50 & $\begin{array}{l}\text { Marly limestone, limestone, sandy } \\
\text { limestone }\end{array}$ \\
\hline & 1.3 & 5 & -------- & -------- & $\begin{array}{c}\text { Marly limestone, limestone (water } \\
\text { bearing zone) }\end{array}$ \\
\hline $\mathbf{L 4}$ & 2.5 & 16 & 11 & 20 & Marl \\
\hline \multirow{2}{*}{$\mathbf{L 5}$} & 39 & 71 & 3 & 7 & $\begin{array}{c}\text { Fractured limestone dry zone of } \\
\text { Layer (5) }\end{array}$ \\
\hline & 1.3 & 6.4 & -------- & ------- & $\begin{array}{c}\text { Fractured limestone (water bearing } \\
\text { zone) }\end{array}$ \\
\hline L6 & 60 & 112 & 5 & 12.6 & Oolitic limestone \\
\hline
\end{tabular}

As will be discussed later, the northern part of the third layer is downthrown towards the north. The part of the layer at the downthrown side is subdivided into two zones; an upper dry zone and a lower water-bearing one. The wide range of resistivity of the layer at the southern part and the dry zone at the northern part is mainly attributed to horizontal lithological facies change from marly limestone (relatively low resistivity) to limestone

Egyptian J. Desert Res., 70, No. 2, 153-171 (2020) 
(moderate resistivity) to sandy limestone (relatively high resistivity). Actually, this layer attains a resistivity ranging from 13 to $72 \mathrm{Ohmm}$ in most of the study area, while higher resistivity values (90 to $157 \mathrm{Ohmm}$ ) are restricted to the southeastern part of the study area. The fifth layer is subdivided into two zones; the upper one is dry fractured limestone and the lower one is water-bearing fractured limestone. The base of the waterbearing zone was not reached. This layer represents a water-bearing zone in the northern parts of the area.

Correlation of the geoelectrical parameters along four cross-sections resulted in the general subsurface lithological composition, according to the resistivity distribution, and the horizontal extensions and thicknesses of the layering succession in the study area (Fig. 7). The cross-section AA' traverses the area in $\mathrm{S}-\mathrm{N}$ direction and cross-section $\mathrm{BB}^{\prime}$ traverses the area in SE-NW direction, whereas, the cross-sections CC' and DD' traverse the area in W-E direction.

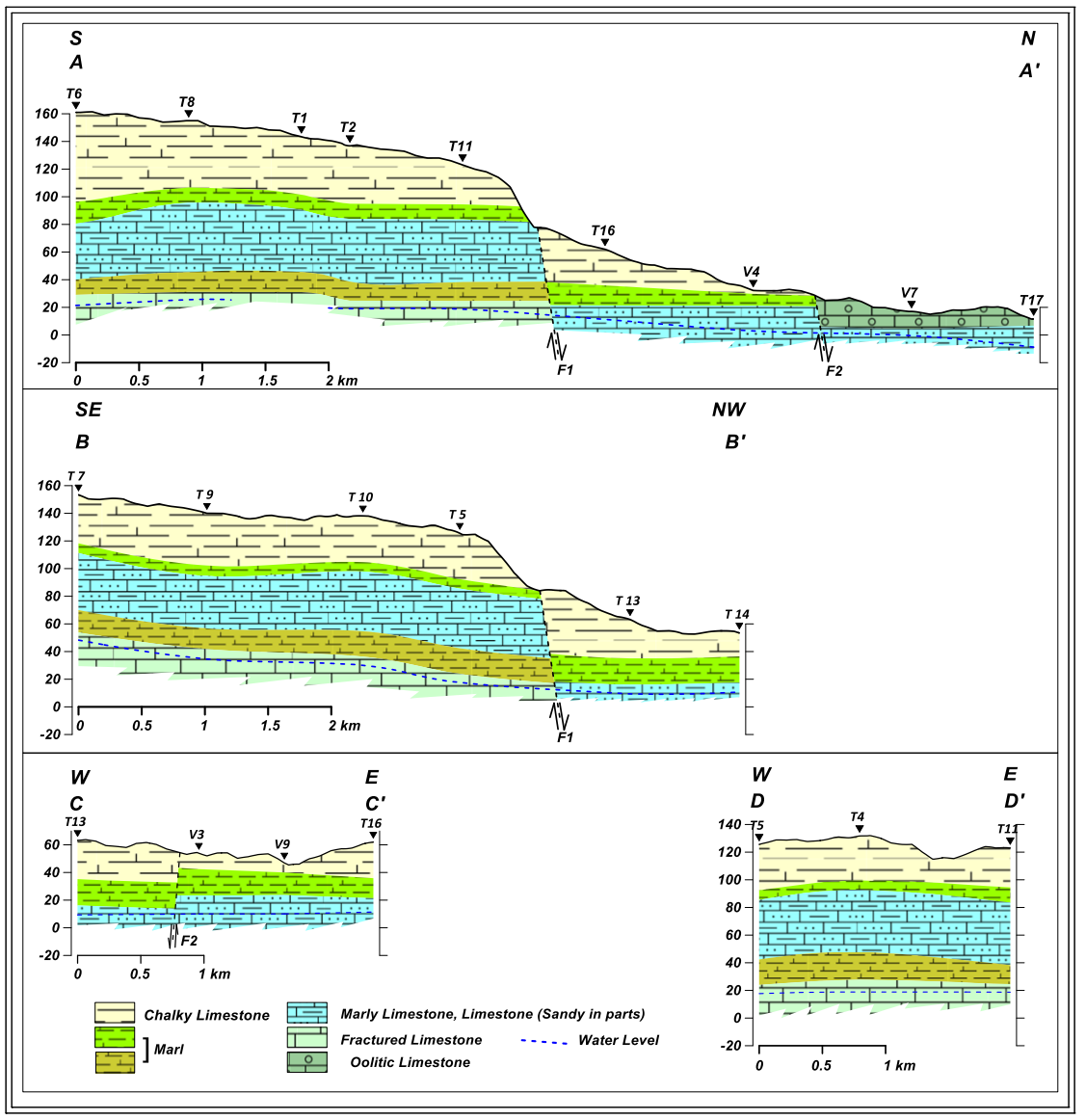

Fig. (7). Geoelectrical cross-sections in the study area.

Egyptian J. Desert Res., 70, No. 2, 153-171 (2020) 
The correlation of the geoelectrical parameters on the cross-sections indicated that the concerned area is affected by two faults (Fig. 8). The first one (F1) strikes in E-W direction with its downthrown side towards North, while the other fault (F2) strikes in NE-SW direction with its downthrown side towards NW. The Iso-resistivity contour map of the water-bearing zones (Fig. 9A) clearly depicts a northward decrease in resistivity, which is mainly due to increase in water salinity at this direction. The groundwater level contour map (Fig. 9B) shows a gradual groundwater flow from south to north.

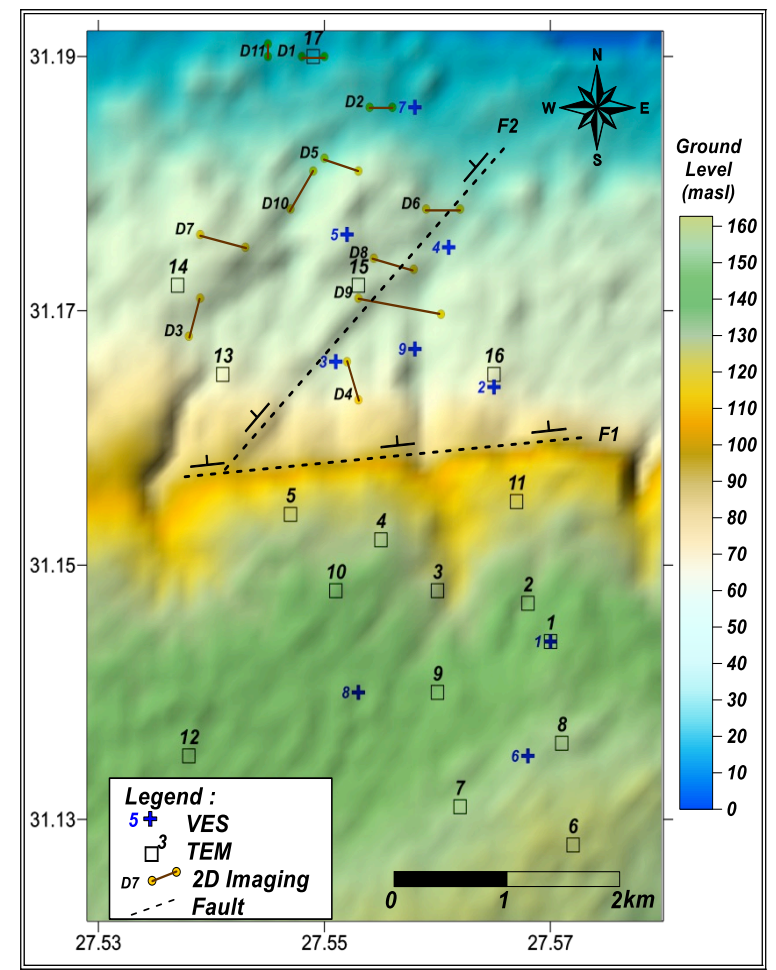

Fig. (8). Inferred faults in the study area. 


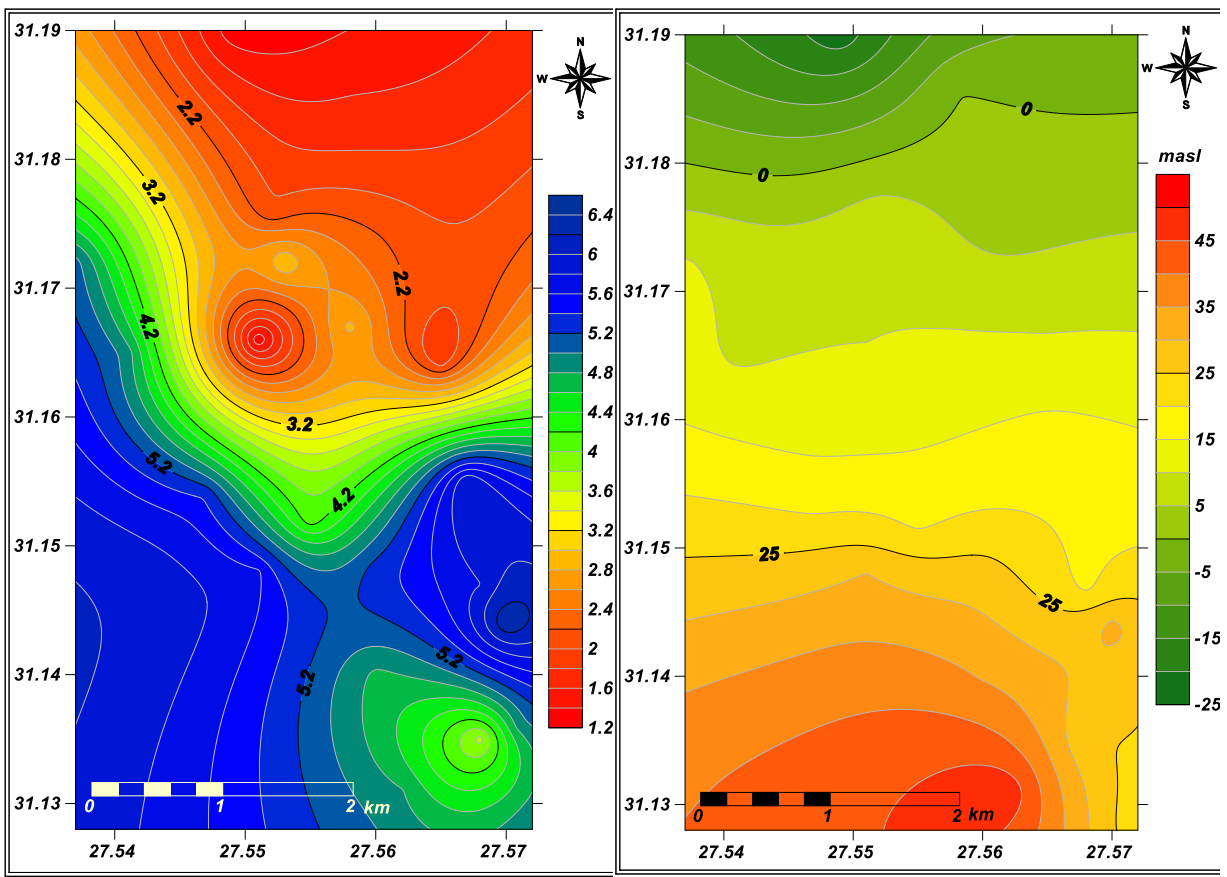

(A)

(B)

Fig. (9). (A) Iso-resistivity contour map of the water-bearing zones, and (B) Groundwater level contour map

The inversion results of the $2 \mathrm{D}$ electrical resistivity tomography (ERT) provided continuous coverage of the resistivity distribution along the measured profiles, through which, the subsurface geological features were resolved. The given information was integrated with the inversion results of the VES and TEM measurements to reach a reasonable perception of the subsurface layering succession including the water-bearing zones. The inversion results of 11 ERT profiles are shown in fig. (10).

Obviously, there is a lot of similarity between ERT results and VES as well as TEM results. This similarity is represented by the following features:

- Each layer shows a lateral variation in resistivity reflecting lithological facies changes or fracturing effect. This feature confirms the wide range of resistivity in the same layer as resulted from VES and TEM inversion.

- The water level is resolved at levels; more or less agree with that detected from the VES and TEM results.

- The faults, which were inferred along the geoelectrical cross-section are clearly detected on some ERT profiles. 


\section{The ERT profiles showed some other features such as:}

- The wadi channels, which are crossed by the ERT profiles, are well resolved and the exhibited resistivities within the channels correspond to alluvial deposits. Two wadi channels, representing such a case, are obviously resolved on ERT profile (9) as well as Profile (10), which was measured along a tributary of Wadi Sakhr.

- The marked water level on the ERT profiles shows, in most cases, an undulated surface due to the characteristics of the water-bearing formation such as the lithological changes and fracturing which control the degree of saturation and water flow direction.

- The ERT results showed differences in the resistivity values of the waterbearing zones, which can be attributed to differences in the water salinity and/or lithological changes.

- The water-bearing zones within the wadi channels show different resistivity values from that within the tableland or pediment plain. The water-bearing zones within the wadi channel represent the alluvium shallow aquifer, whereas, the other zones represent the Carbonate Middle Miocene aquifer.

- The ERT profile located at the vicinity of the shore (Profiles 1, 2, and 11) showed water-bearing zones with low resistivity values which are, mostly, attributed to the effect of seawater.

\section{CONCLUSION}

An integrated geophysical survey including Vertical Electrical Sounding (VES), Transient Electromagnetic (TEM), and Electrical Resistivity Tomography (ERT) was conducted in the area of Wadi Sakhr, Northwestern Coastal Zone of Egypt. The inversion results of both VES and TEM sounding data revealed the presence of a subsurface succession consists of five layers, which were identified as a top chalky limestone layer underlain by a marl layer, followed by the third layer which is laterally changed from marly limestone to limestone to sandy limestone. The fourth layer was found to consist of marl, which is underlain by a layer consists of fractured limestone. The sixth layer corresponds to Oolitic limestone capping the succession at the northern part of the study area. The waterbearing zones were detected within the lower part of the third layer at the northern parts of the area and the lower part of the fifth layer. Two faults were inferred in the study area striking in E-W and NE-SW directions. The ERT inversion results confirmed, to a great extent, that the VES and TEM results resolved several subsurface features. The ERT profiles detected the irregular water level due to the lithological changes and fracturing which control the degree of saturation and water flow direction. Several ERT profiles resolved the subsurface configuration of the Wadi channels and the existing alluvium shallow aquifer. The ERT results showed differences in

Egyptian J. Desert Res., 70, No. 2, 153-171 (2020) 
the resistivity values of the water-bearing zones, which can be attributed to differences in the water salinity and/or lithological changes.
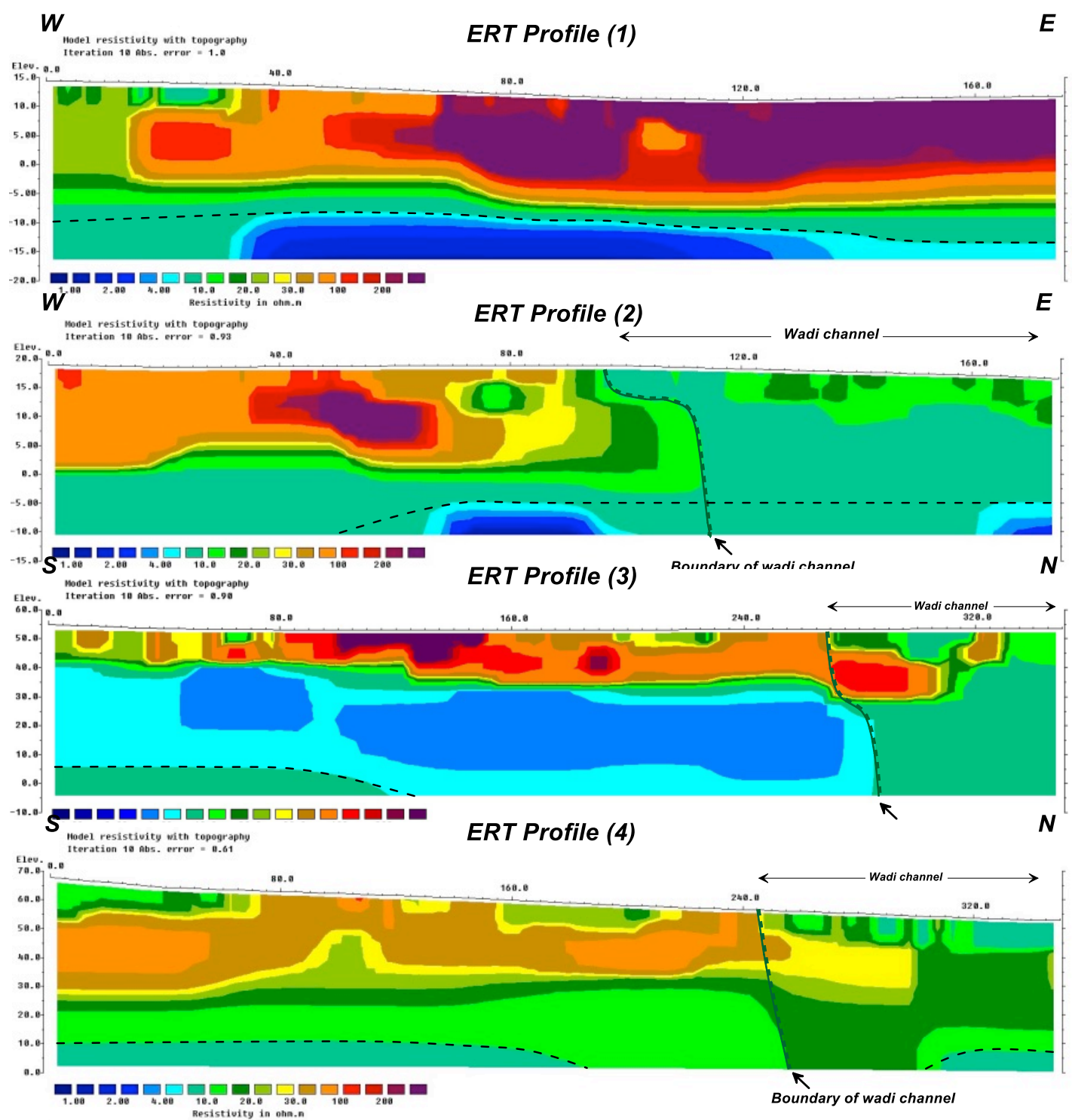

Fig. (10). Inversion models of ERT profiles.

Egyptian J. Desert Res., 70, No. 2, 153-171 (2020) 

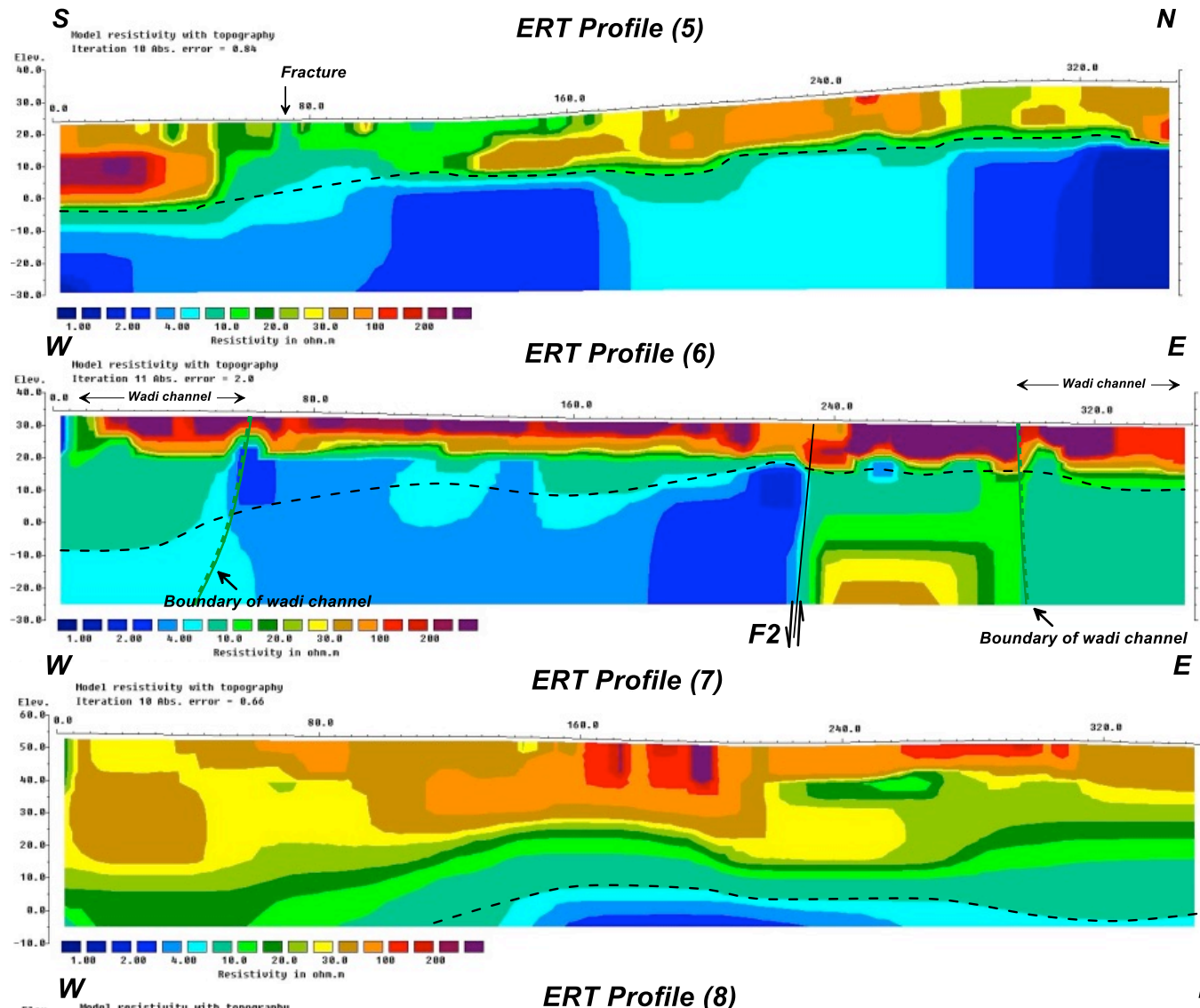

ERT Profile (7)
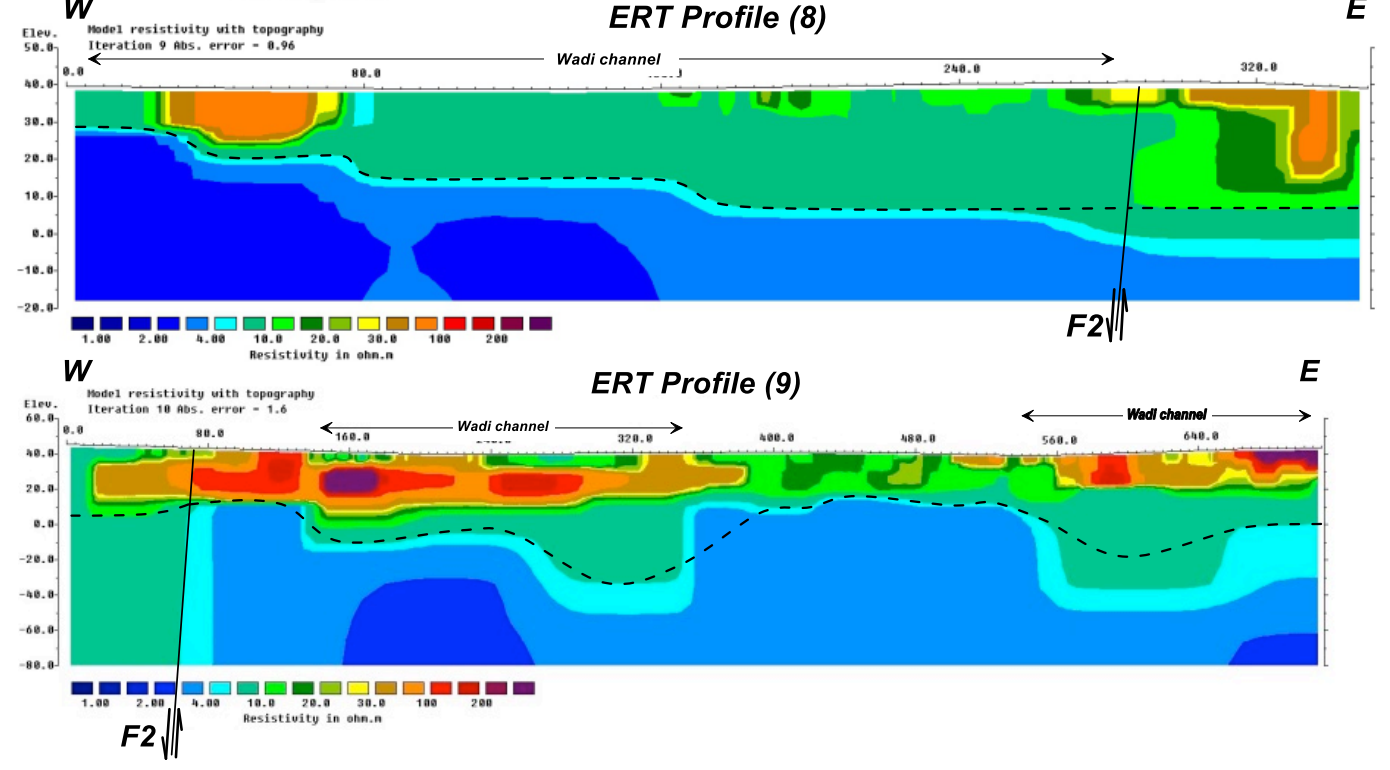

Fig. (10). (Cont.)

Egyptian J. Desert Res., 70, No. 2, 153-171 (2020) 


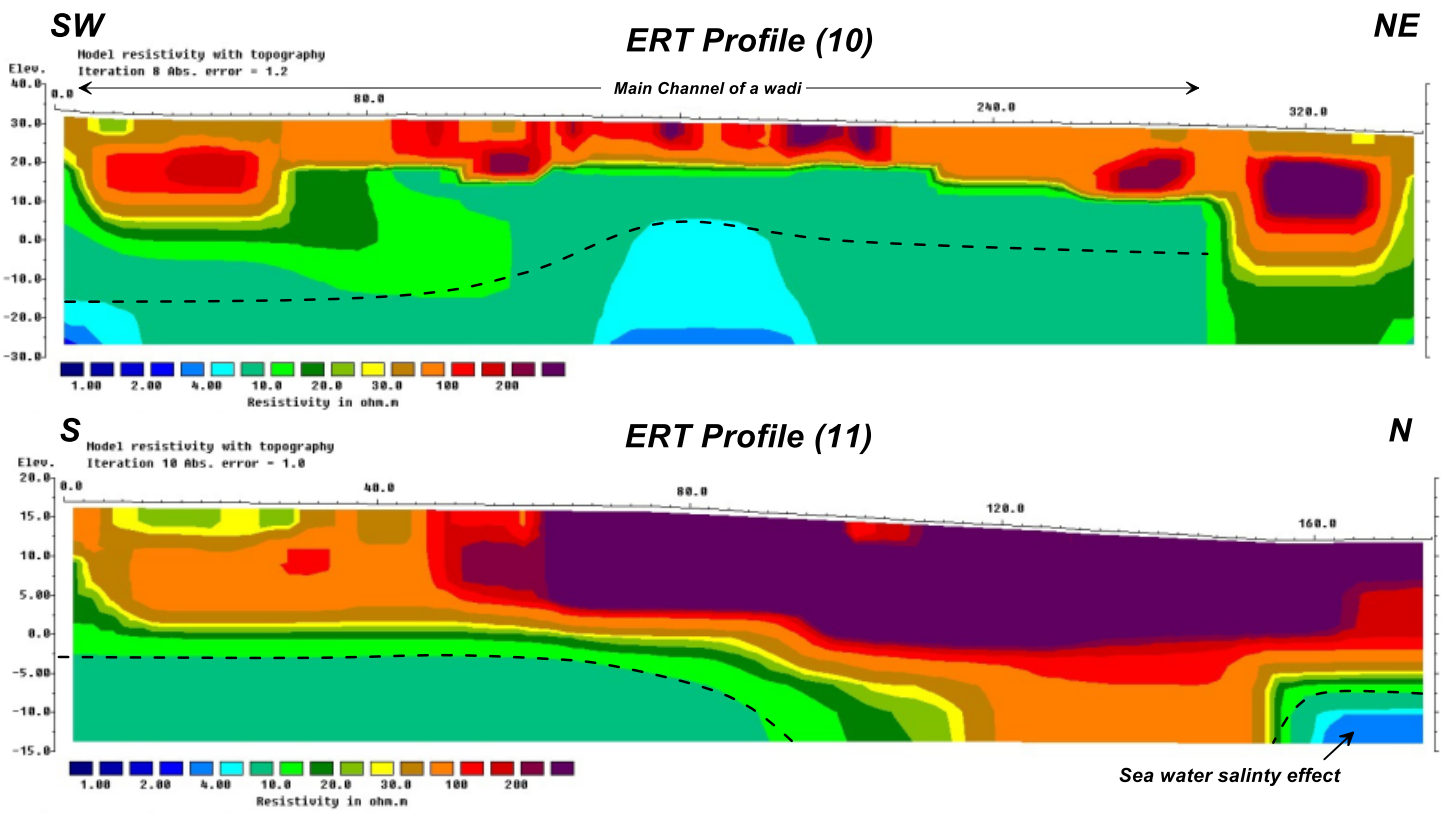

Fig. (10). (Cont.)

\section{ACKNOWLEDGMENT}

The author deeply indebted to the spirit of Prof. Dr. M.Y. Draz the principal investigator of "Sustainable Agriculture Development of the Northwestern Coast of Egypt, El-Qassaba-Bagoush Basin" project, which is financed by ACSAD, for the permission to use some of the field data in this article.

\section{REFERENCES}

Abdel Moghith, S.A., A.A. Taha and F.A. Hammad (1978). Hydrogeological studies on the tertiary and quaternary aquifers along the Coastal Zone of Egypt and Libya. Water Resources Inst., Cairo Int. Report.

CONOCO (1986). Geological map of Egypt, Scale 1: 500,000 GPC. Sheet No. NH35NE.

Dahlin, T. (1996). 2D resistivity surveying for environmental and engineering applications. First Break, 14: 275-284.

Desert Research Center (2012). Groundwater potential in Northwestern Coast. Progress Report (phase II) Ras El Hekma-Sidi Barani (in Arabic), $110 \mathrm{p}$.

Egyptian J. Desert Res., 70, No. 2, 153-171 (2020) 
Desert Research Center (2018). Geoelectric and electromagnetic study on groundwater setting in Wadi Sakhr Basin, North Western Coast (in Arabic). Final report submitted to ACSAD.

El-Sharabi, E.S. (2000). Hydrogeological, geomorphological and geoenvironmental implications for future sustainable development of the Northwestern Coast Zone of Egypt. Ph.D. Thesis, Mansoura University.

El-Maghraby, M. (1997). Geophysical, hydrogeological and remote sensing studies on the effect of sea level fluctuation on the groundwater reservoir between Alexandria and El Dabaa, Egypt. Ph.D. Thesis, Fac. Sci., Alex. Univ.

El-Raey, M. (1998). Framework of integrated coastal area management of the Fuka-Matrouh area, Egypt. PAP/RAC-37-1995.

El-Shazly, M.M. (1970). Contribution to the geochemistry of the groundwater in Mersa Matrouh area, Western Mediterranean Coastal Zone, Egypt. Bull. Inst. Desert, Cairo, 20 (2): 289-299.

Hammad, F.A. (1972). The geology of the soil and water resources in the area between Ras El-Hekma and Ras Ala El-Rum, Western Mediterranean Littoral zone, Egypt. Egypt, Ph.D. Thesis, Fac. Sci., Cairo Univ.

Flores, C. and N. Velasco (1998). A comparative analysis between transient electromagnetic soundings and resistivity soundings in the Tres Virgenes geothermal zone, Mexico. Geofísica Internacional, 37 (3): 183-199.

Geotom Software (2009). RES2DINV.EXE ver. 3.59.121, Geotom Software Sdn Bhd, Malausia.

Interpex (2008). 1X1D (v. 3.39), Interpex Ltd., Golden Colorado, USA.

Loke, M.H., J.E. Chambers, D.F. Rucker, O. Kuras and P.B. Wilkinson (2013). Recent developments in the direct-current geoelectrical imaging method. Journal of Applied Geophysics, 95: 135-156.

Morad, N.A., M.H. Masoud and S.A. Abdel Moghith (2014). Hydrologic factors controlling groundwater salinity in Northwestern Coastal Zone, Egypt. J. Earth Syst. Sci., 123 (7): 1567-1578.

Raslan, S.M. (1995). Geomorphological and hydrogeological studies on some localities along the Northwestern Coast of Egypt. M.Sc. Thesis, Fac. Sci., Menofia Univ., Egypt.

Said (1962). In: "The Geology of Egypt". Elsevier, Amsterdam, New York.

Sewiden, A.S. (1978). Water budget analysis for the Northwestern Coastal Zone. Ph.D. Thesis, Fac. Sci., Cairo Univ.

Shaaban, F.A. (2004). Geophysical evaluation of the groundwater potentiality, Southeastern Matrouh area, Egypt. NRIAG J., Special Issue: 243-266.

Egyptian J. Desert Res., 70, No. 2, 153-171 (2020) 
Shata, A. (1957). Geology and geomorphology of the Wadi ElKharruba area, Western Desert, Mediterranean littoral, Matrouh District, Egypt. Bull. Inst. Desert D' Egypt, (10): 91-120.

Soliman, M.M. (2005). Environmental and geophysical assessment of the groundwater and subsurface water resources of Ras El Hekma area, Northwestern Coast of Egypt. Ph.D. Thesis, Fac. Sci., Ain Shams Univ.

Yousif, M., E. El-Abd, A. Baraka (2013). Assessment of water resources in some drainage basins, Northwestern Coast, Egypt,. Appl. Water Science, 3: 439-452.

Egyptian J. Desert Res., 70, No. 2, 153-171 (2020) 


\title{
استكشاف خزانات المياه الجوفية باستخدام التقتيات الجيوكهربية بوادي

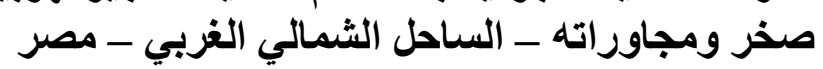

\section{محمد زغلول توفيق علي}

قسم الاستكثاف الجيوفيزيائي، مركز بحوث بلئ الصحر اء، المطرية، القاهرة

\begin{abstract}
تم مسح منطقة وادي صخر بالساحل الثمالي الغربي باستخدام التقنيات الجيوفيزيائية

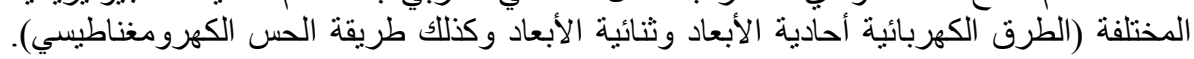

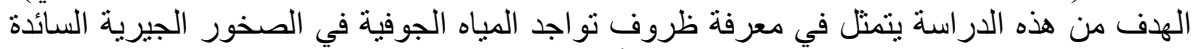

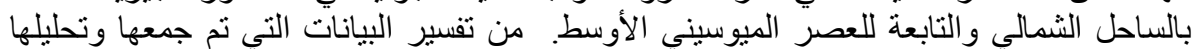

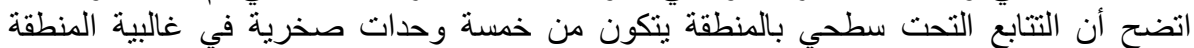

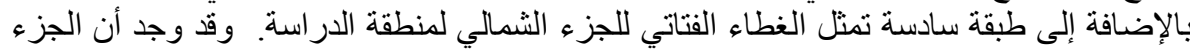

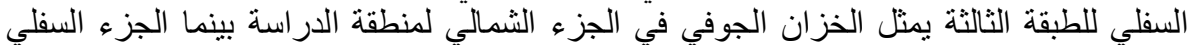

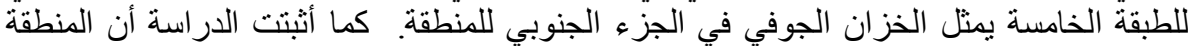
تتأثر بفالقين رئيسيين يمتدان في اتجاه شمال غرب - جنوب شرق.
\end{abstract}

Egyptian J. Desert Res., 70, No. 2, 153-171 (2020) 